\title{
HUMAN PLACENTAL PHOSPHOGLUCOMUTASE LOCUS 3 STUDIES IN THE ITALIAN POPULATION
}

\author{
R.M. Corbo, ${ }^{1}$ R. Palmarino, ${ }^{1}$ G.F. Spennati, ${ }^{2}$ \\ R. PASCONE, ${ }^{3}$ and P. LUCARELLII ${ }^{1}$ \\ ${ }^{1}$ National Research Council, Center of Evolutionary Genetics, \\ University of Rome, Rome, Italy \\ ${ }^{2}$ Paediatric Clinics of $S$. Salvatore Hospital, L'Aquila \\ ${ }^{3}$ Department of Child Health, University of Rome, \\ Rome, Italy
}

\begin{abstract}
Summary Phosphoglucomutase locus $3\left(\mathrm{PGM}_{3}\right)$ phenotypes have been examined in placental samples from a total of 532 Italian subjects. The $\mathrm{PGM}_{3}$ similarity in some different ethnic groups excludes this polymorphism from the useful anthropological markers.
\end{abstract}

\section{INTRODUCTION}

Phosphoglucomutase is a phosphotransferase [EC 2.7.5.1] which catalyses the reversible transformation of glucose-1-phosphate to glucose-6-phosphate. Different molecular forms of human phosphoglucomutase exist which are controlled by three different structural loci, $\mathrm{PGM}_{1}, \mathrm{PGM}_{2}$ and $\mathrm{PGM}_{3}$, each with several alleles. Only $\mathrm{PGM}_{1}$ and $\mathrm{PGM}_{3}$ have been found polymorphic in all the populations so far examined (Spencer et al., 1964; Hopkinson and Harris, 1964; Hopkinson and Harris, 1968; Ishimoto, 1969; Lamm, 1970; Herzog and Drdova, 1971; Monn and Gjønnaess, 1971; Van Wierst et al., 1973; Blake and Omoto, 1975; Donald, 1977).

$\mathrm{PGM}_{3}$ population studies have been fairly limited. This is due both to the necessity of requiring material other than red cells to determine $\mathrm{PGM}_{3}$ phenotypes and to the electrophoretic changes caused by the progressive generation of more anodal "secondary" isozymes at the expense of the "primary" enzyme form (Fisher and Harris, 1972).

This report concerns samples obtained from six different Italian districts and examined for this genetic marker. 


\section{MATERIALS AND METHODS}

Placentae were consecutively collected in the regional hospitals of Rome, l'Aquila, Pavia, Cagliari, Sassari and Nuoro. The samples were immediately frozen at $-20^{\circ} \mathrm{C}$. The tissue aqueous extracts were generally made within 15 days from delivery and examined within $24 \mathrm{hr}$ according to Harris and Hopkinson (1976) (Fig. 1).

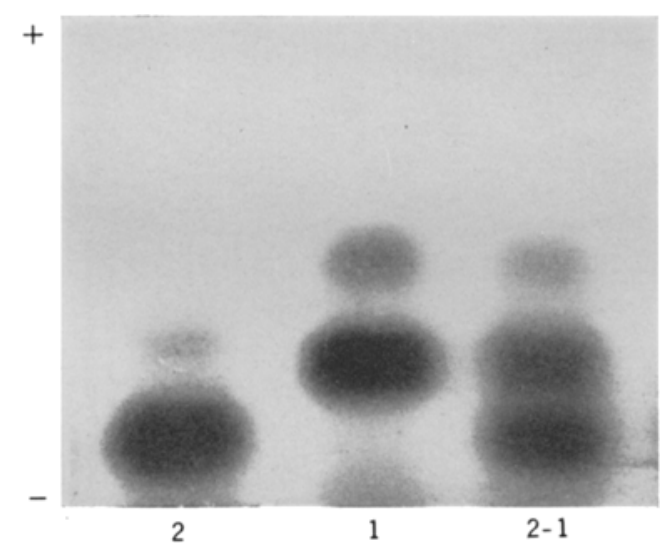

Fig. 1. $\mathrm{PGM}_{3}$ common electrophoretic phenotypes.

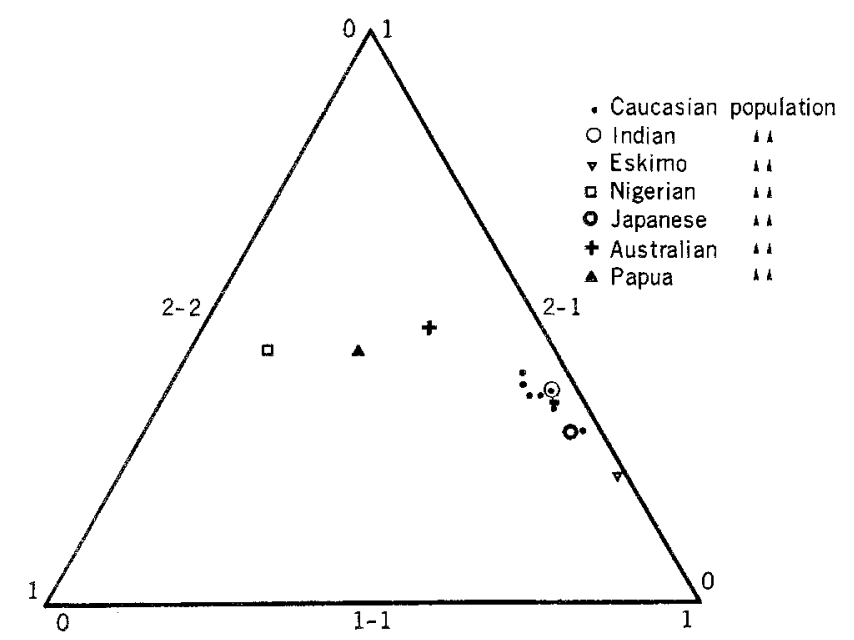

Fig. 2. Graphic representation of the world distribution of the $\mathrm{PGM}_{3}$ genotypic frequencies. 
Table 1. Phenotypes and gene frequencies in six Italian districts.

\begin{tabular}{|c|c|c|c|c|c|c|c|}
\hline \multirow{2}{*}{ Population } & & \multicolumn{4}{|c|}{ Phenotypes } & \multicolumn{2}{|c|}{ Alleles } \\
\hline & & 1 & $2-1$ & 2 & Total & $\mathrm{PGM}_{3}{ }^{1}$ & $\mathrm{PGM}_{3}{ }^{2}$ \\
\hline \multirow[t]{2}{*}{ Roma } & $n^{\circ}$ & 49 & 29 & 0 & 78 & 0.81 & 0.19 \\
\hline & $\%$ & 0.63 & 0.37 & 0.00 & & & \\
\hline \multirow[t]{2}{*}{ L'Aquila } & $\mathrm{n}^{0}$ & 59 & 39 & 7 & 105 & 0.75 & 0.25 \\
\hline & $\%$ & 0.56 & 0.37 & 0.07 & & & \\
\hline \multirow[t]{2}{*}{ Pavia } & $n^{\circ}$ & 79 & 38 & 6 & 123 & 0.80 & 0.20 \\
\hline & $\%$ & 0.64 & 0.31 & 0.05 & & & \\
\hline \multirow[t]{2}{*}{ Sassari } & $n^{0}$ & 24 & 10 & 4 & 38 & 0.76 & 0.24 \\
\hline & $\%$ & 0.63 & 0.26 & 0.11 & & & \\
\hline \multirow[t]{2}{*}{ Cagliari } & $\mathrm{n}^{\circ}$ & 62 & 30 & 6 & 98 & 0.79 & 0.81 \\
\hline & $\%$ & 0.63 & 0.31 & 0.06 & & & \\
\hline \multirow[t]{2}{*}{ Nuoro } & $\mathrm{n}^{\circ}$ & 70 & 40 & 7 & 117 & 0.77 & 0.23 \\
\hline & $\%$ & 0.60 & 0.34 & 0.06 & & & \\
\hline \multirow[t]{3}{*}{ Italy } & $\mathrm{n}^{\circ}$ & 343 & 186 & 30 & 559 & 0.78 & 0.22 \\
\hline & $\%$ & 0.61 & 0.33 & 0.05 & & & \\
\hline & $\chi^{2} 1$ d.f. & 0.02 & 0.17 & 0.33 & $0.52 *$ & & \\
\hline
\end{tabular}

* Calculated to test the Hardy-Weinberg equilibrium.

Table 2. $\mathrm{PGM}_{3}$ gene frequencies in all the populations examined up to now.

\begin{tabular}{|c|c|c|c|c|}
\hline \multirow{2}{*}{ Population } & \multirow{2}{*}{$\begin{array}{l}\mathrm{N}^{\circ} \text { of } \\
\text { subjects }\end{array}$} & \multicolumn{2}{|c|}{ Gene frequencies } & \multirow{2}{*}{ References } \\
\hline & & $\mathrm{PGM}_{3}{ }^{1}$ & $\mathrm{PGM}_{3}^{2}$ & \\
\hline Norwegian (Norway) & 660 & 0.73 & 0.27 & Monn and Gjønnaess (1971) \\
\hline Danish (Denmark) & 1,031 & 0.75 & 0.25 & Lamm (1970) \\
\hline English (England) & 583 & 0.74 & 0.26 & Hopkinson and Harris (1968) \\
\hline German (North Germany) & 74 & 0.82 & 0.18 & Ritter (1976) \\
\hline German (South-Western Germany) & 289 & 0.77 & 0.23 & Bissbort et al. (1975) \\
\hline Italian (Italy) & 532 & 0.78 & 0.22 & present investigation \\
\hline Czechoslovak (Czechoslovakia) & 146 & 0.76 & 0.24 & Herzog and Drdova (1971) \\
\hline SWO-Caucasian (Canada) & 1,382 & 0.77 & 0.23 & Donald (1977) \\
\hline SWO-Random (Canada) & 1,468 & 0.76 & 0.24 & Donald (1977) \\
\hline Indian (Canada) & 230 & 0.77 & 0.23 & Donald (1977) \\
\hline Eskimo (Canada) & 82 & 0.88 & 0.12 & Donald (1977) \\
\hline Nigerian (England) & 235 & 0.34 & 0.66 & Hopkinson and Harris (1968) \\
\hline Japanese (Japan) & 370 & 0.81 & 0.19 & Ishimoto $(1969)$ \\
\hline White Australian (Canberra) & 205 & 0.78 & 0.22 & Van Wierst et al. (1973) \\
\hline Aborigene Australian (Australia) & 101 & 0.59 & 0.41 & Van Wierst et al. (1973) \\
\hline Papua New Guincan (Papua) & 191 & 0.51 & 0.48 & Van Wierst et al. (1973) \\
\hline
\end{tabular}

Vol. 25 , No. 4, 1980 


\section{RESULTS AND DISCUSSION}

The distribution of the $\mathrm{PGM}_{3}$ phenotypes observed in the six Italian samples and the corresponding gene frequencies are shown in Table 1.

Analysis of the results showed similar $\mathrm{PGM}_{3}$ gene frequencies in all six groups (Homogeneity: $\chi^{2}=2.59$, d.f. $5, \mathrm{P}$ n.s.). They were therefore combined and comprise the Italian population. Investigations carried out up to now (Table 2) show some ethnic differences but the position of some populations in terms of $\mathrm{PGM}_{3}$ gene frequencies seems to exclude this system from the useful anthropological markers (Fig. 2).

\section{REFERENCES}

Blake, N.M., and Omoto, K. 1975. Phosphoglucomutase types in the Asian-Pacific area: a critical review including new phenotypes. Ann. Hum. Genet. 38: 251-273.

Bissbort, S., Kömpf, J., Bethge, C., and Gussmann, S. 1975. Population genetics of human red cell phosphoglucomutase isozyme PGM $_{3}$. Humangenetik 27: 57-62.

Donald, L.J. 1977. Placental enzyme polymorphisms in Canadian populations. Hum. Hered. 27: $280-284$.

Fisher, R.A., and Harris, H. 1972. "Secondary" isozymes derived from the three PGM loci. Ann. Hum. Genet. London 36: 69-77.

Harris, H., and Hopkinson, D.A. 1976. Handbook of enzyme electrophoresis in human genetics. North Holland Publ., Amsterdam.

Herzog, P., and Drdova, A. 1971. Contribution to the $\mathbf{P G M}_{3}$ polymorphism phenotype frequencies in Prague. Humangenetik 13: 64-65.

Hopkinson, D.A., and Harris, H. 1965. Evidence for a second "structural" locus determining human phosphoglucomutase. Nature 208: 410-412.

Hopkinson, D.A., and Harris, H. 1968. A third phosphoglucomutase locus in man. Ann. Hum. Genet. 31: 359-367.

Ishimoto, G. 1969. Placental phosphoglucomutase in Japan. Jpn. J. Human Genet. 14: 183-188.

Lamm, L.U. 1970. Family, population and mother-child studies of two phosphoglucomutase loci $\left(\mathrm{PGM}_{1}\right.$ and $\left.\mathrm{PGM}_{3}\right)$. Hum. Hered. 20: 292-304.

Monn, E., and Gjønnaess, H. 1971. Placental phosphoglucomutase types in Norway. Hum. Hered. $21:$ 254-262.

Ritter, H. quoted by Mourant, A.E., Kopeć, A.C., Domaniewska-Sobczak, K 1976. The Distribution of the Human Blood Groups and other Polymorphisms. 2nd Ed., London Oxford University Press, New York, Toronto.

Spencer, N., Hopkinson, D.A., and Harris, H. 1964. Phosphoglucomutase polymorphism in man. Nature 204: 742-745.

Van Wierst, B., Blake, N.M., Kirk, R.L., Jacobs, D.S., and Johnson,D.G. 1973. Genetic variation at the third locus of phosphoglucomutase in placentas from Australia and Papua New Guinea. Austr. J. Exp. Biol. Med. Sci. 51: 857-860. 